\title{
Hasil Belajar Matematika Siswa dengan Menggunakan Model Pembelajaran Kooperatif Tipe Group Investigation (GI) pada Siswa Kelas VII SMP N 3 Tigo Nagari Tahun Pelajaran 2018/2019
}

\author{
Syafrio Roni Wirdayat ${ }^{1}$, M.Imamuddin,M.Pd ${ }^{2}$, dan Dr. Muhiddinur Kamal, M.Pd ${ }^{3}$ \\ ${ }_{1,2,3}$ Pendidikan Matematika, Institut Agama Islam Negeri Bukittinggi \\ e-mail: syafrisyafriorhoni@gmail.com
}

\begin{abstract}
ABSTRAK. Tujuan untuk mengetahui apakah hasil belajar matematika siswa yang mengikuti model pembelajaran kooperatif tipe Group Investigation (GI) lebih baik daripada yang mengikuti pembelajaran konvensional pada mata pelajaran matematika di kelas VII SMP N 3 Tigo Nagari tahun pelajaran 2018/ 2019. Jenis penelitian ini adalah pra-eksperimen dengan rancangan penelitian The Static Group Comparison Design. Populasi dalam penelitian ini adalah seluruh siswa kelas VII SMP N 3 Tigo Nagari tahun pelajaran 2018/ 2019. Pengambilan sampel dilakukan secara acak. Populasi dalam penelitian ini adalah seluruh siswa kelas VII SMP N 3 Tigo Nagari Tahun Pelajaran 2018/2019 sebanyak 87 orang siswa yang terdiri dari 3 kelas. Sampel pada penelitian ini adalah siswa kelas VII.B sebagai kelas eksperimen dan siswa kelas VII.C sebagai kelas kontrol. Data penelitian hasil belajar diperoleh dari tes uji coba. Rata-rata nilai tes pada kelas eksperimen adalah 75.66 dan kelas kontrol 65.55 dengan $t_{\text {hitung }}=2.91$ dan $t_{\text {tabel }}=1.67$. Selanjutnya hasil analisis menunjukkan bahwa hasil belajar matematika siswa yang mengikuti model pembelajaran kooperatif tipe Group Investigation (GI) lebih baik daripada yang mengikuti pembelajaran Konvensional pada mata pelajaran matematika di kelas VII SMP N 3 Tigo Nagari tahun pelajaran 2018/ 2019.
\end{abstract}

Kata kunci: hasil belajar, model pembelajaran kooperatif tipe group investigation (GI),

\section{PENDAHULUAN}

Pendidikan bagi kehidupan umat manusia merupakan kebutuhan mutlak yang harus dipenuhi sepanjang hayat. Tanpa pendidikan mustahil suatu kelompok manusia dapat hidup berkembang sejalan dengan aspirasi untuk maju, bahagia dan sejahtera. Pendidikan merupakan salah satu cara pembentukan manusia untuk berpikir rasional dan efisien dalam menghadapi masalah-masalah yang timbul dalam kehidupan. Seperti yang dijelaskan oleh undang-undang Pendidikan Nasional Nomor 20 tahun 2003:

Pendidikan menurut Undang-Undang Nomor 20 tahun 2003 tentang Pendidikan Nasional adalah usaha sadar dan terencana untuk mewujudkan suasana belajar dan proses pembelajaran agar peserta didik secara aktif mengembangkan potensi dirinya untuk memiliki kekuatan spiritual keagamaan, pengendalian diri, kepribadian, kecerdasan, akhlak mulia, serta keterampilan yang diperlukan dirinya, masyarakat, bangsa dan Negara (Wina Sanjaya, 2008).

Secara detail, dalam Peraturan Menteri Pendidikan dan Kebudayaan Nomor 58 Tahun 2014 bahwa tujuan pembelajaran matematika adalah sebagai berikut :

1. Memahami konsep matematika, merupakan kompetensi dalam menjelaskan keterkaitan antarkonsep dan menggunakan konsep maupun algoritma, secara luwes, akurat, efisien, dan tepat, dalam pemecahan masalah.

2. Menggunakan pola sebagai dugaan dalam penyelesaian masalah, dan mampu membuat generalisasi berdasarkan fenomena atau data yang ada.

3. Menggunakan penalaran pada sifat, melakukan manipulasi matematika baik dalam 
penyederhanaan, maupun menganalisa komponen yang ada dalam pemecahan masalah dalam konteks matematika maupun di luar matematika (kehidupan nyata, ilmu, dan teknologi) yang meliputi kemampuan memahami masalah, membangun model matematika, menyelesaikan model dan menafsirkan solusi yang diperolehtermasuk dalam rangka memecahkan masalah dalam kehidupan sehari-hari (dunia nyata).

4. Mengkomunikasikan gagasan, penalaran serta mampu menyusun bukti matematika dengan menggunakan kalimat lengkap, simbol, tabel, diagram, atau media lain untuk memperjelas keadaan atau masalah.

5. Memiliki sikap menghargai kegunaan matematika dalam kehidupan, yaitu memiliki rasa ingin tahu, perhatian, dan minat dalam mempelajari matematika, serta sikap ulet dan percaya diri dalam pemecahan masalah.

6. Memiliki sikap dan perilaku yang sesuai dengan nilai-nilai dalam matematika dan pembelajarannya, seperti taat azas, konsisten, menjunjung tinggi kesepakatan, toleran, menghargai pendapat orang lain, santun, demokrasi, ulet, tangguh, kreatif, menghargai kesemestaan (konteks, lingkungan), kerjasama, adil, jujur, teliti, cermat, bersikap luwes dan terbuka, memiliki kemauan berbagi rasa dengan orang lain.

7. Melakukan kegiatan-kegiatan motorik yang menggunakan pengetahuan matematika

8. Menggunakan alat peraga sederhana maupun hasil teknologi untuk melakukan kegiatankegiatan matematika.

Salah satu cabang ilmu dalam dunia pendidikan adalah matematika. Matematika adalah ilmu yang mempelajari tentang tata cara berpikir dan mengolah logika baik secara kuantitatif maupun secara kualitatif (Erman Suherman, 2003). Banyak permasalahan dan kegiatan dalam hidup kita yang harus diselesaikan dengan menggunakan ilmu matematika seperti menghitung, mengukur, dan lain-lain. Tujuan pembelajaran matematika di sekolah mengacu kepada fungsi matematika kepada tujuan pendidikan nasional yang telah dirumuskan dalam Garis-Garis Besar Haluan Negeri (GBHN). Diungkapkan dalam Garis-Garis Besar Program Pengajaran (GBPP) matematika, ada dua tujuan umum diberikannya pembelajaran matematika pada jenjang pendidikan dasar dan menengah, yaitu:

1. Mempersiapkan siswa agar sanggup menghadapi perubahan keadaan di dalam kehidupan di dunia yang selalu berkembang, melalui latihan bertindak atas dasar pemikiran secara logis, rasional, kritis, cermat, jujur, efektif dan efisien.

2. Mempersiapkan siswa agar dapat menggunakan matematika dan pola pikir matematika dalam kehidupan sehari-hari, dan dalam mempelajari berbagai ilmu pengetahuan (Erman Suherman, 2003).

Salah satu peranan matematika dalam tujuan umum pendidikan matematika di atas adalah untuk mempersiapkan siswa agar mampu menghadapi perubahan keadaan atau tantangantantangan di dalam kehidupan dan di dunia yang selalu berkembang. Persiapan-persiapan itu dapat dilakukan melalui latihan membuat kesimpulan dan keputusan atas dasar pemikiran logis, kritis, jujur, efektif dan efisien.

Aktivitas belajar yang ditunjukkan selama proses pembelajaran matematika masih rendah serta kurangnya motivasi siswa dalam proses pembelajaran sehingga ketuntasan hasil belajar siswa belum maksimal. Kondisi ini juga penulis temukan di SMP N 3 Tigo Nagari. Hal ini terlihat dari masih banyaknya nilai Ujian Tengah Semester siswa belum mencapai Kriteria Ketuntasan Minimal (KKM). terlihat bahwa proses pembelajaran yang berlangsung masih terpusat pada guru. Metode yang dipakai adalah metode ekspositori. Proses pembelajaran diawali dengan penjelasan materi oleh guru, dilanjutkan dengan pemberian contoh soal, kemudian siswa diberi kesempatan untuk mencatatnya di buku masing-masing. Setelah itu guru memberikan beberapa buah soal dan menyuruh siswa mengerjakan soal-soal tersebut dibuku latihan, saat guru menjelaskan materi dan memberikan contoh soal sebagian siswa cukup paham dan sebagian siswa masih banyak bermain 
dan tidak memperhatikan saat guru menjelaskan. Saat guru memberikan soal yang sedikit berbeda dengan contoh soal yang diberikan sebelumnya, pada umumnya siswa cenderung tidak dapat mengerjakan. Umumnya siswa hanya menunggu jawaban dari teman yang bisa atau menunggu penjelasan dari guru, tanpa mau berusaha dan berfikir untuk menyelesaikannya sendiri terlebih dahulu. Itulah salah satu penyebab rendahnya hasil belajar siswa.

Selama proses pembelajaran terlihat bahwa rendahnya aktivitas, dan kurangnya respon siswa pada saat guru menerangkan pelajaran di depan kelas, hal tersebut terlihat pada waktu guru menjelaskan pembelajaran masih banyak yang melakukan kegiatan yang lain selain proses pembelajaran matematika. Berdasarkan wawancara yang penulis lakukan dengan beberapa orang siswa menurut mereka matematika itu adalah pelajaran yang kurang mengasikkan, sulit untuk dipahami, dan pelajaran matematika terlalu banyak rumus-rumus yang harus dihafal, sehingga menyebabkan siswa malas dalam melaksanakan pembelajaran matematika, apalagi ditambah dengan suasana kelas yang membosankan dan monoton karena pembelajaran selalu terpusat pada guru yang menyebabkan siswa merasa bosan dalam belajar matematika. Sebagian siswa juga mengaku apabila diberi contoh soal mereka dapat memahami, tetapi setelah diberikan soal yang berbeda mereka mengaku kesulitan dalam menjawab soal tersebut, dan jika di beri soal untuk dikerjakan sendiri mereka malah mengerjakan berdua atau mencontek jawaban dari teman yang telah siap mengerjakan soal tersebut. Sehingga mereka tidak dapat menyelesaikannya. Kebanyakan siswa mengulang pelajaran di rumah ketika ada PR saja dan ada yang tidak mengerjakan sama sekali dengan alasan tidak mengerti.

Berdasarkan uraian di atas, diduga bahwa salah satu penyebab rendahnya hasil belajar matematika siswa yang sangat berpengaruh adalah siswa kurang memahami dalam menyelesaikan soal-soal yang disajikan saat ujian. Karena model dan bentuk soal yang diberikan tidak sama dengan yang pernah dikerjakan atau dibahas pada saat proses pembelajaran. Hal ini diakibatkan karena kurangnya pemahaman siswa terhadap materi yang telah diajarkan, kurangnya perhatian siswa dalam belajar matematika. Umumnya siswa hanya menghafal apa yang pernah dia coba sebelumnya tanpa memahami bagaimana cara dan proses untuk menyelesaikan suatu persoalan yang diberikan.

Permasalahan di atas yang ditemui dalam proses pembelajaran matematika tidak dapat dibiarkan secara terus-menerus. Oleh karena itu guru dituntut menciptakan kondisi pembelajaran yang memungkinkan siswa terlibat secara aktif. Hal ini sejalan dengan pendapat yang dikemukakan oleh Oemar Hamalik yang menyatakan bahwa dengan terlibatnya siswa secara aktif dalam pembelajaran, maka siswa mampu memperoleh pengetahuan, pemahaman, dan keterampilan serta perilaku lainnya, termasuk sikap dan nilai (Oemar Hamalik, 2013). Maka dari itu dibutuhkan suatu model pembelajaran yang tidak berpusat pada guru, dapat melibatkan peran siswa secara aktif, serta dapat meningkatkan motivasi siswa dalam memahami materi yang dipelajari, bertanggung jawab terhadap tugasnya dan bisa meningkatkan hasil belajar. Model yang dimaksud adalah model pembelajaran kooperatif tipe Group Investigation (GI).

Model pembelajaran kooperatif merupakan bentuk pembelajaran dengan cara siswa belajar dalam kelompok- kelompok kecil secara kolaboratif yang anggotanya terdiri dari empat sampai enam orang dengan struktur kelompok yang bersifat heterogen. Model pembelajaran kooperatif dikembangkan untuk mencapai setidak-tidaknya tiga tujuan pembelajaran penting, yaitu hasil belajar akademik, penerimaan terhadap keragaman dan pengembangan keterampilan sosial. Berdasarkan hasil penelitian yang dilakukan oleh Slavin menyatakan pembelajaran kooperatif dapat meningkatkan prestasi belajar siswa dan sekaligus dapat meningkatkan hubungan sosial (Rusman, 2012).

Model pembelajaran kooperatif tipe Group Investigation (GI) merupakan model pembelajaran yang menekankan pada aktivitas belajar siswa untuk mencari dan menemukan sendiri fakta, konsep, dan prinsip. Penelitian yang paling luas dan sukses dalam meningkatkan 
hasil dari metode-metode spesialisasi tugas adalah investigasi kelompok, sebuah pembelajaran kooperatif yang berasal dari zamannya John Dewey, tetapi telah diperbaharui dan diteliti pada beberapa tahun terakhir ini oleh Sholmo dan Yael Shahran (Mulyanto Widodo, 2016). Model Pembelajaran Group Investigation (GI) dapat memadukan antar siswa yang berbeda kemampuan melalui kelompok yang heterogen, melatih siswa untuk meningkatkan kerjasama dalam kelompok, melatih siswa untuk bertanggungjawab sebab ia diberi tugas untuk diselesaikan dalam kelompok, siswa dilatih untuk menemukan hal-hal baru dari hasil kelompok yang dilakukan, melatih siswa untuk mengeluarkan ide dan gagasan baru melalui penemuan yang ditemukannya dan dapat meningkatkan hasil belajar siswa. Berdasarkan hasil penelitian yang dilakukan oleh Anugerah Bate'e menyatakan kualiatas proses pembelajaran matematika baik, motivasi belajar baik dan rata-rata hasil belajar siswa baik melalui model pembelajaran kooperatif tipe Group Investigation.

Hasil penelitian yang dilakukan oleh (Anugerah Bate'e, 2015)mengatakan menyatakan bahwa kualitas proses pembelajaran matematika baik melalui penerapan model pembelajaran kooperatif tipe Group investigation, motivasi belajar siswa baik melalui penerapan model pembelajaran kooperatif tipe Group investigation dan rata-rata hasil belajar matematika siswa melalui penerapan model pembelajaran kooperatif tipe Group investigation lebih baik daripada hasil belajar matematika siswa dengan konvensional.

Selanjutnya, hasil penelitian yang dilakukan oleh (Febditya Aji Wijaya, dkk, 2018) dapat diketahui bahwa Upaya peningkatan hasil belajar menggunakan Group Investigation pada siswa kelas 4 sekolah dasa. Penelitian ini bertujuan untuk mengetahui hasil bejar siswa yang diberikan melalui model pembelajaran Group Investigation. Bahwa dinyatakan model pembelajaran Group Investigation dapat meningkatkan hasil belajar siswa.

\section{METODE}

Jenis penelitian yang digunakan adalah penelitian eksperimen, dengan rancangan yang digunakan adalah the static group comparison design. Sampel dibagi menjadi dua kelompok, yaitu kelas eksperimen dan kelas kontrol. Perlakuan yang diberikan pada kelas eksperimen adalah menggunakan model pembelajaran Kooperatif Tipe Group Investigation sedangkan pada kelas kontrol menggunakan model pembelajaran konvensional.

Lokasi yang dijadikan tempat penelitian ini ialah SMP N 3 Tigo Nagari yang berada di Padang Ranjau, Kecamatan Tigo Nagari. Kabupaten Pasaman. Waktu pelaksanaan penelitian dimulai dari tanggal 12 November sampai 5 Desember 2018.

Penelitian ini memiliki populasi yaitu seluruh siswa kelas VII SMP N 3 Tigo Nagari. Sampel yang diambil adalah secara acak dengan pengambilan dua kelas yang berbeda yang memiliki data homogen yang dilihat dari rata-rata nilai ulangan harian, sehingga terpilihlah kelas VII.B dan kelas VII.C sebagai kelas eksperimen dan kelas kontrol.

Instrumen penelitian yang digunakan untuk memperoleh data yang diperlukan dalam penelitian ini yaitu berupa instrumen tes. Tes yang diberikan adalah tes berbentuk essay. Karena tes essay dapat mendorong siswa untuk mengorganisasikan dan mengintegrasikan ide-idenya sendiri. Soal yang dibuat kemudian di uji kelayakannya. Maksudnya adalah soal yang digunakan sudah memenuhi kriteria validitas soal, reliabilitas soal, indeks kesukaran soal, dan daya pembeda soal. Hasil belajar matematika dengan menggunakan model pembelajaran kooperatif tipe Group Investigation (GI) ini dianggap layak untuk digunakan dalam penelitian.

Data yang diperoleh dalam penelitian ini berasal dari data kuantitatif. Data kuantitatif diperoleh dari tes hasil belajar matematika siswa dengan menggunakan model pembelajaran kooperatif tipe Group investigation (GI) . Data tersebut dianalisis. Selanjutnya dilakukan 
perhitungan dengan melakukan pengujian diantaranya yaitu uji normalitas, uji homogenitas, dan uji kesamaan rata-rata dan uji t. Data yang telah diperoleh kemudian diolah dengan menggunakan software minitab dan Microsoft excel 2010.

\section{HASIL DAN PEMBAHASAN}

Setelah dilakukan tes hasil belajar, diperoleh data tentang hasil belajar matematika siswa. Tes hasil belajar ini diikuti oleh 29 orang siswa dari kelas eksperimen dan 29 orang siswa dari kelas control. Hasil penelitian yang dilakukan dengan taraf yang signifkan $\alpha=0,05$ menunjukkan bahwa terdapat perbedaan antara kelas eksperimen dan kelas kontrol dimana kelas eksperimen dalam pembelajarannya menggunakan model pembelajaran kooperatif tipe Group Investigation sedangkan kelas kontrol menggunakan pembelajaran konvensional. Rata-rata nilai tes pada kelas eksperimen adalah 75.66 dan kelas kontrol 65.55 dengan $t_{\text {hitung }}=2.91$ dan $t_{\text {tabel }}=1.67$.

Hasil belajar matematika siswa dengan menggunakan model pembelajaran kooperatif tipe Group Investigation (GI) lebih baik daripada siswa yang mengikuti pembelajaran konvensional. Berdasarkan hasil deskripsi dan analisis data tes hasil belajar siswa terlihat bahwa hasil belajar matematika siswa kelas eksperimen lebih baik daripada hasil belajar matematika siswa kelas kontrol. Hal ini dapat dilihat dari nilai rata-rata siswa kelas eksperimen lebih tinggi dari pada nilai rata-rata siswa kelas kontrol. Nilai rata-rata kelas eksperimen adalah 75.66. Sedangkan nilai ratarata kelas kontrol adalah 65.55. Dilihat dari Kriteria Ketuntasan Minimal (KKM) yang telah ditetapkan, maka kelas eksperimen memiliki jumlah persentase ketuntasan sebesar $80 \%$ dan kelas kontrol sebesar 45\%. Jadi dapat disimpulkan bahwa persentase jumlah siswa kelas eksperimen yang berada di atas Kriteria Ketuntasan Minimal (KKM) lebih besar daripada kelas kontrol.

\section{Pembahasan}

Secara umum pembelajaran dengan menggunakan model pembelajaran kooperatif tipe Group Investigation (GI) lebih baik daripada siswa yang mengikuti pembelajaran konvensional. Model pembelajaran kooperatif merupakan bentuk pembelajaran dengan cara siswa belajar dalam kelompok- kelompok kecil secara kolaboratif yang anggotanya terdiri dari empat sampai enam orang dengan struktur kelompok yang bersifat heterogen. Sehingga membuat masing-masing siswa dapat belajar dengan anggota kelompoknya secara efektif. Perbedaan uji hitung yang dilakukan antara kelas yang dijadikan sebagai kelas eksperimen dengan kelas kontrol 10.11 lebih baik kelas eksperimen daripada kelas kontrol. Ini menyatakan bahwa kelas eksperimen yang menggunakan model pembelajaran kooperatif tipe Group Investigation (GI) lebih baik dibandingkan dengan model konvensional.

\section{KESIMPULAN}

Berdasarkan hasil analisis data penelitian rata-rata nilai tes pada kelas eksperimen adalah 75.66 dan kelas kontrol 65.55 dengan $t_{\text {hitung }}=2.91$ dan $t_{\text {tabel }}=1.67$. Maka dapat disimpulkan bahwa hasil belajar matematika siswa dengan menggunakan model pembelajaran kooperatif tipe Group Investigation (GI) lebih baik daripada model pembelajaran konvensional (ekspositori) di kelas VII SMP N 3 Tigo Nagari Tahun Pelajaran 2018/2019

\section{REFERENSI}

Anugerah Bate'e. (2015). Penerapan Model Pembelajaran Kooperatif Tipe Group Investigation Untuk Meningkatkan Motivasi Dan Hasil Belajar Matematika SD Negeri 4 Idanogaw. Jurnal bina gogik vol. 2. Medan: Universitas Negeri Medan.

Oemar Hamalik. (2013). Kurikulum dan Pembelajaran. Jakarta: Bumi Aksara. 
Rusman. (2012). Model-Model Pembelajaran: Mengembangkan Profesionalisme Guru. Jakarta: PT Raja Grafindo Persada.

Wina Sanjaya. (2008). Strategi Pembelajaran Berorientasi Standar Proses Pendidikan. Jakarta: Kencana Prenanda Media Group.

Erman Suherman. (2003). Strategi Pembelajaran Matematika Kontemporer. Bandung: JICA.

Wijaya, Aji, Febditya, Dkk. (2018). Upaya Peningkatan Hasil Belajar Menggunakan Group Investigation Pada Siswa Kelas 4 SD. Jurnal Widyagogik vol. 5. Temanggung: Universitas Kristen Satya Wacana. 